\title{
К ИСТОРИИ КАРАДАГСКОЙ НАУЧНОЙ СТАНЦИИ ИМ. Т.И. ВЯЗЕМСКОГО
}

\author{
Костенко Н.С. \\ ФГБУН «Карадагская научная станџия им. Т.И.Вяземского - природный заповедник РАН», \\ 2. Феодосия, Российская Федерация, karadag1914@mail.ru
}

Рассмотрены основные этапы деятельности Карадагской научной станции им. Т.И. Вяземского с момента ее зарождения и дальнейшего функционирования на протяжении столетия (1914-2014) и последующего ее возрождения в 2015 г. по решению Правительства Российской Федерации.

Ключевые слова: Карадагская научная станция им. Т.И. Вяземского, Карадагское отделение Института биологии южных морей, Карадагский природный заповедник.

\section{Введение}

Карадагская научная станция им. Т.И. Вяземского имеет удивительную историю. Станция зародилась в одном из глухих уголков России - Восточном Крыму, воплотив в себя идеи ее основателей из Московского университета - приват-доцента доктора медицины Т.И. Вяземского, врача-психиатра и невропатолога, и его соратника профессора Л.З. Мороховца, создавшего институт Физиологии при Московском университете. Как показало изучение архивных материалов - переписки Т.И. Вяземского и Л.З. Мороховца, оба ученых были энтузиастами создания станции (Мороховец, 2016). Организация станции осуществлялась при непосредственном участии старейшего в России Московского общества испытателей природы (МОИП), основанного при старейшем и крупнейшем очаге просвещения - Московском университете. Главными руководителями и деятелями общества являлись профессора или другие научные сотрудники Московского университета.

Станция прошла долгий и трудный путь своего развития: от идеи создания станции, ее строительства, дальнейшего воплощения и развития в сложном вихре событий ХХ века. Особая роль здесь принадлежит А.Ф. Слудскому - душеприказчику Т.И. Вяземского и заведующему станцией. В письме А.Ф. Слудского к академику А.П. Павлову от 30.07.1917 г. дается характеристика Карадага: «... в переживаемые дни Карадаг остается благословенным местом... душа тянет на Карадаг - здесь я нужнее, здесь больше опасностей для создаваемого детища Терентия Ивановича, которое с таким трудом растет и так еще слабо и хило, что боязно оставить его сиротой...» (Владимиров, Владимирова, 2008, с. 56). Уже в 1917 г. академиком А.П. Павловым было подано заявление в Комитет по охране владений участков, имеющих особое значение - научное и историческое, в котором мотивировалась необходимость особого охранения Карадагской научной станции.

Как показал исторический опыт, станция на Карадаге послужила своеобразным магнитом, притягивающим в последующие десятилетия ее существования и становления многих ученых России, в том числе геологов, биологов и других естествоиспытателей.

Развитию станции содействовали такие крупные ученые, как академики А.П. Павлов, Ф.Ю. Левинсон-Лессинг, А.Д. Архангельский, Д.Н. Прянишников, И.А. Каблуков, А.А. Богомолец, А.В. Палладин, И.И. Шмальгаузен, а также профессора Д.В. Соколов, Н.В. Ермаков, директора станции А.Ф. Слудский, В.Л. Паули, К.А. Виноградов и др.

Судьбой станции были обеспокоены выдающиеся ученые, и прежде всего ее первый заведующий А.Ф. Слудский, что нашло отражение в его эпистолярном наследии. Директор станции профессор К.А. Виноградов неоднократно подводил итоги деятельности станции в своих публикациях. Им осуществлялась эвакуация станции и ее возрождение после окончания Великой отечественной войны. Благодаря деятельности директоров-энтузиастов станция 
обустраивалась: проводились коммуникации (дорога, водопровод), строилось жилье. В 70-е годы прошлого века, когда директором была А.Л. Морозова, были построены дельфинарий, котельная, дом для сотрудников. Налаживался быт ученых, развивались новые научные направления.

\section{Результаты и обсуждение}

Вековая история Карадагской научной станции не забыта и поныне. Исторический путь станции отражен в ряде работ (Слудский, 2004 б, 2009; Виноградов, 1947 а, б; 1958; 2009; Смирнов, 1959; Пузанов, 1965; Понизовский, 1965; Михаленок, 1997, 1999; Клюкин, 2004; Морозова, 2001, 2006; Морозова и др., 1989).

Так, в настоящее время студентам Московского университета читаются лекции по истории биостанций, в том числе и Карадагской. Появление биостанций - научных и педагогических учреждений, обеспечивающих возможность стационарного исследования живых организмов в природных условиях, было необходимым этапом в развитии естествознания. Каждая биостанция имеет особую историю и свою роль в развитии науки (Колотилова, 2013).

О значении Карадагской станции в период ее вхождения в Московское общество испытателей природы (МОИП) с 1922 по 1930 гг. свидетельствуют исторические материалы, из которых следует, что общество «имело в своем распоряжении несколько научных станций. Особенно ценной станцией являлась Карадагская станция в Крыму, которая была передана Наркомпросом обществу в 1922 г. Ранее эта станция была в ведении Леденцовского общества. Территория этой станции являлась весьма выгодной в естественно-историческом отношении: она представляет древний вулкан, а близость моря позволяла заняться изучением морской флоры и фауны. Карадагская биологическая станция обладала большой естественноисторической библиотекой, которая была собрана ее основателем - доктором Вяземским и пожертвована станции, а также хорошо оборудованными лабораториями. На ней проводили ботанические, геологические и зоологические работы как московские члены общества, так и студенты и посторонние обществу ученые. В 1930 г. станция эта была отторгнута от общества, претерпела ряд тяжелых организационных моментов...» (Липшиц, 1940). Когда Карадагская биологическая станция состояла в ведении МОИП, было опубликовано 2 выпуска «Трудов» станции в 1930 (Вып. 3) и 1931 (Вып. 4) гг. В этот период станция вела большую просветительскую работу: в экскурсиях за лето участвовало до 3-4 тыс. человек.

Несколько лет (1931-1936 гг.) Карадагская станция находилась в ведении Наркомпроса Крымской АССР. В 1933 г. было изменено название, она становится естественно-научной станцией. В 1937 г. она переведена в подчинение Академии наук УССР. Президиум Академии наук УССР по предложению Ученого Света Карадагской биологической станции принял решение считать 23 сентября датой рождения станции и включения ее в семью научных учреждений. В 1963 г. Карадагская биостанция была реорганизована в Карадагское отделение созданного в г. Севастополе Института биологии южных морей (ИнБЮМ). В 1979 г. постановлением правительства УССР в системе АН УССР был создан Карадагский государственный заповедник, который на правах отдела входил в состав Карадагского отделения ИнБЮМ. Таким образом была претворена в жизнь идея, озвученная еще основателями станции и ведущими учеными того времени - организовать на землях станции заповедник. С 1997 г. Карадагская биостанция на правах научного отдела вошла в состав Карадагского природного заповедника НАН Украины, который в этот период становится юридическим лицом (табл.).

Примечательно, что еще 50 лет назад И.И. Пузанов (1965) писал: «Карадагская станция должна быть восстановлена в качестве полноценной биологической станции, которая 
необходима ученым всего Советского Союза». Такое время наступило. Вторым рождением Карадагской научной станции им. Т.И. Вяземского следует считать 2015 г., когда Распоряжением Правительства Российской Федерации от 7 сентября 2015 г. № 1743-р создано научное учреждение ФГБУН «Карадагская научная станция им. Т.И. Вяземского - природный заповедник РАН».

В 2016 г. одновременно существует два юридических лица - учреждение регионального уровня Государственное бюджетное учреждение науки и охраны природы Республики Крым «Карадагский природный заповедник» и Федеральное государственное учреждение науки «Карадагская научная станция - природный заповедник РАН», учредителем которого является ФАНО России.

Почти 100 лет назад станция заявила о себе выходом в свет 1 выпуска «Трудов» в 1917 г. Важнейший этапы деятельности станции и даты выпуска «Трудов» (с 1 по 18), а также основной печатной продукции, выходившей с участием сотрудников, работавших на Карадаге, отображены в таблице. Много лет на станции проработала ветеран Великой отечественной войны кандидат биологических наук Л.Н. Згуровская, которая выйдя на заслуженный отдых, популяризировала природу Крыма и Карадага, написав 10 научно-популярных книг, которые пользуются большим спросом. Книги с авторством Л.Н. Згуровской, стали своеобразным брендом научно-популярной литературы о Крыме, что нашло свое отражение в таблице.

Таблица 1.

Основные этапы деятельности Карадагской научной станции им. Т.И. Вяземского

\begin{tabular}{|c|c|c|}
\hline Годы & События & $\begin{array}{c}\text { Пояснения к событиям. Направления } \\
\text { исследований. Руководители станции. } \\
\text { Основные публикации } \\
\end{array}$ \\
\hline 1901 & $\begin{array}{l}\text { Приобретение Т.И. Вяземским участка земли } \\
\text { (имение Н.С. Вишневской) в урочище Карадаг. } \\
\text { Единственный здесь одноэтажный дом был } \\
\text { надстроен вторым этажом и выстроен отдельный } \\
\text { корпус в } 10 \text { комнат. }\end{array}$ & $\begin{array}{l}\text { Т.И. Вяземский решил организовать санаторий } \\
\text { для нервно- и психически-больных. Доход от } \\
\text { санатория он предполагал использовать для } \\
\text { постройки биологической станции. }\end{array}$ \\
\hline 1907 & $\begin{array}{l} \\
\text { Начало строительства научной станции на } \\
\text { Карадаге. Помощь оказали Л.З. Мороховец } \\
\text { (Московский университет), предоставивший деньги } \\
\text { для строительства лабораторного корпуса и здания } \\
\text { для сотрудников, и С.С. Крым, давший } \\
\text { Т.И. Вяземскому банковский кредит. }\end{array}$ & \\
\hline 1913 & & $\begin{array}{l}\text { Издано: Слудский А.Ф. Карадаг (в Крыму), его } \\
\text { естественнонаучное значение, научная и } \\
\text { промышленная будущность. Доклад, } \\
\text { прочитанный в годичном общем собрании } \\
\text { Общества содействия успехам опытных наук и их } \\
\text { практических применений имени Х.С. Леденцова } \\
\text { 2-го декабря } 1912 \text { г. - М.: Типография «Русская } \\
\text { печатия», } 1913\end{array}$ \\
\hline
\end{tabular}


1914 Окончание строительства лабораторного корпуса Карадагской научной станции, в жилом корпусе заканчивалась внутренняя отделка.

Станцию предполагалось связать с Физиологическим институтом Московского университета.

Т.И. Вяземский решил передать станцию в надежные руки, общественной организации, которая взяла бы на себя дальнейшую заботу о ней - Обществу содействия успехам опытных наук и их практических применений им. Х.С. Леденцова. Для руководства организацией и деятельностью станции от Общества назначена комиссия под председательством А.П. Павлова, в составе И.А. Каблукова, Н.И. Кудякова, Т.И. Вяземского, А.Ф. Слудского и Н.А. Умова.

25.03.1914. На заседании Совета Общества им. Х.С. Леденцова при Московском университете и Московском техническом училище обсуждался вопрос о принятии дара Т.И. Вяземского - станции и участка земли при ней в 2 десятины 987 кв. саженей и библиотеки, насчитывающей 40000 книг. Т.И. Вяземский рассматривал свое собрание книг как общенародное достояние. Т.И. Вяземскому было поручено дальнейшее управление станцией. 24.04.1914. Станция получила свой устав и под названием «Карадагской научной станции» вошла в список научных институтов.

16.05.1914. Оформление завещания Т.И. Вяземского в собственность Общества им. Х.С. Леденцова движимого и недвижимого имущества, которое бы служило целям и нуждам научной станции на Карадаге.

19.05.1914. На заседании совета Общества им. Х.С. Леденцова состоялась юридическая передача станции Обществу на условиях, оговоренных Советом Общества на заседании 25.03.1914. 23.09.1914. День смерти Т.И. Вяземского. На заседании совета Общества им. Х.С. Леденцова Карадагской научной станции присвоено имя Т.И. Вяземского. По завещанию Т.И. Вяземского станции перешло все его владение на Карадаге.

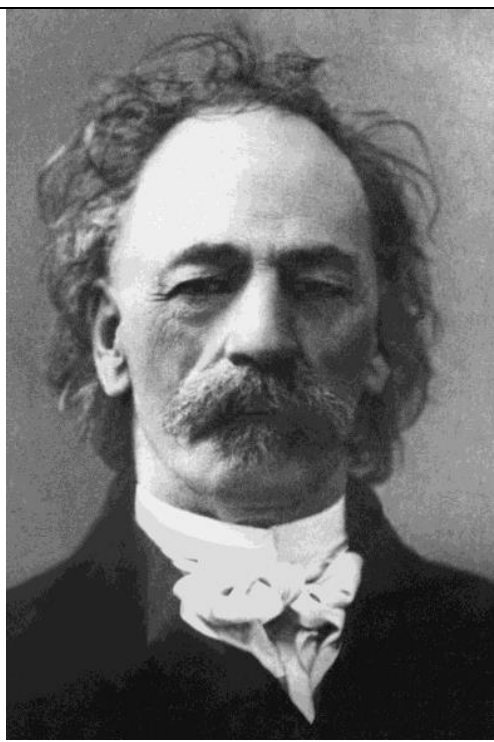

Доктор медицины Т.И. Вяземский -заведующий станцией в 1914 г.

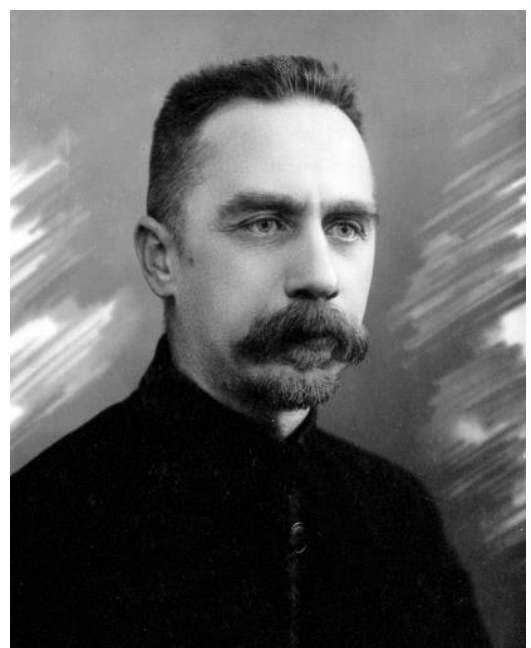

Профессор А.Ф. Слудский - заведующий станцией в 1914-1927 гг. Назначен Московским университетом.

1915 К лабораторному корпусу пристроено помещение музея. Начало создания станционного музея А.Ф. Слудским и В.Н. Вучетичем. Положено начало декоративным насаждениям на станционном участке.

\begin{tabular}{|c|c|c|}
\hline 1916 & & $\begin{array}{l}\text { Издано: Сарандинаки В.Н. Материалы для флоры } \\
\text { окрестностей г. Феодосии // Известия } \\
\text { Императорского Ботанического Сада Петра } \\
\text { Великого. - 1916. - № 1. - С. 185-223 }\end{array}$ \\
\hline 1917 & $\begin{array}{l}\text { А.Ф. Слудский обратился с предложением принять } \\
\text { КНС в общую семью научных учреждений России. } \\
\text { Была выдвинута идея создания государственного } \\
\text { заповедника. } \\
\text { Заполнив «Опросный лист для учета заповедников } \\
\text { и памятников природы», академик А.П. Павлов } \\
\text { предложил «Сохранить для будущих поколений } \\
\text { исключительно интересную и поучительную } \\
\text { природу данного участка» (п. 9), считая эту } \\
\text { местность «одной из самых поучительных мировых } \\
\text { достопримечательностей» (п. 5). }\end{array}$ & $\begin{array}{l}\text { Издано: Труды Карадагской научной станции имени } \\
\text { Т.И. Вяземского / Под ред. И.А. Каблукова, } \\
\text { А.Ф. Слудского. - Феодосия: Типография Т-ва } \\
\text { Рябушкинских, 1917. - Выпуск 1. - } 115 \text { с.; } \\
\text { Сарандинаки В.Н. Материалы для флоры } \\
\text { окрестностей г. Феодосии. Ч. } 2 \text { (продолжение) // } \\
\text { Известия Императорского Ботанического Сада } \\
\text { Петра Великого. - 1917. - № 1. - С. 1-30; } \\
\text { Сарандинаки В.Н. Материалы для флоры } \\
\text { окрестностей г. Феодосии. Ч. } 2 \text { (окончание) // } \\
\text { Известия Главного Ботанического Сада. - 1917. - № } \\
\text { 1. - С. 179-245. }\end{array}$ \\
\hline
\end{tabular}


1918 14.01.1918. Получено Охранное свидетельство на имущество станции от Военной Комиссии ВоенноРеволюционного комитета по г. Феодосии; 05.03.1918. Получено Охранное свидетельство на научные коллекции и библиотеку от Феодосийского Уездного Совета рабочих, военных и крестьянских депутатов.

11.03.1918. Мандат Земельной управы Феодосийского уездного Земельного комитета выдан Карадагской научной станции им.

Т.И. Вяземского как учреждению «высококультурному, просветительному и общенародному» - для охраны этого народного достояния от всяких посягательств. Это обстоятельство имело огромное значение для дальнейшей истории станции.

8.11.1918. Постановление Президиума ВСНХ РСФСР, согласно которому станция после ликвидации Общества им. Х.С. Леденцова, была передана в ведение научно-технического отдела ВСНХ РСФСР.

1920 27.11.1920. Охранительное свидетельство Отдела народного просвещения Военно-революционного комитета РСФСР - дано в том, что всё имущество Карадагской научной станции является неприкосновенным и взято Феодосийским ОТНАРПРОСОМ под свою охрану. Комендантом г. Феодосии было выдано удостоверение заведующему Карадагской биологической станцией (А.Ф. Слудскому) в том, что помещения ни реквизиции, ни постою в/ч не подлежат.

1922 Станция перешла из системы ВСНХ в систему Народного Комиссариата Просвещения и заведование ею было поручено Главнаукой Московскому обществу испытателей природы (МОИП)

1923 Наркомпрос РСФСР по ходатайству МОИП отпускает ассигнования на достройку здания станции и оборудование лаборатории.

На Карадаге установлена метеорологическая станция, которая начала регулярные наблюдения и вошла в общую метеорологическую сеть.

1924 17.05.1924. Станция снята с госбюджета. Постановление коллегии Наркомзема Крыма об отводе научной станции под Национальный парк 1500 десятин лесного массива

1925 17.02.1925. Постановлением Совнаркома РСФСР Карадагская Научная Станция им. Т.И. Вяземского официально оформлена как научноисследовательское учреждение и включена в ведение Главнауки РСФСР и содержание ее было принято на государственный бюджет. Структура станции получила законодательную форму в виде утвержденного устава. Станция стала равноправным членом общей сети научноисследовательских институтов Союза и получила возможность планомерно развивать свои дальнейшие работы. Это исследования по геологии, зоологии, ботанике, метеорологии.
В 1918 г. гражданская война и иностранная интервенция прервали связь между Крымом и Москвой. Станция вела самостоятельное существование.

Благодаря ходатайству М.А. Волошина приняты меры по сохранению имущества Карадагской научной станции и его библиотеки, за что А.Ф. Слудский был ему чрезвычайно признателен.

Издано: Труды Карадагской научной станции имени Т.И. Вяземского. - Феодосия: Типолитография Центральной Станции ГидроМетеорологической Службы, 1918. - Выпуск 2. Часть 1. -26 с.

1918-1920 гг. - период неопределенного положения станции - до установления советской власти на всей территории страны.

Станция состояла на госбюджете, находясь в ведении Главнауки РСФСР.

В 1922-1924 гг. профессор А.В. Вознесенский провел магнитную съемку Карадага.

Возобновляются научные работы на станции.

Издано: Слудский А.Ф. О Национальном парке на Карадаге. - Феодосия: 3-я гостипо-литография, 1924. - 7 c.

Проведение геологической съемки Карадага (академик Ф.Ю. Левинсон-Лессинг, Е.Н. Дьяконова-Савельева), палеонтологические исследования (академики А.П. Павлов, М.В. Павлова), ботанико-географические (В.Н. Сарандинаки), изучение фауны насекомых (А.М. Дьяконов) и млекопитающих (К.К. Флеров) 


\begin{tabular}{|c|c|c|}
\hline 02.1926 & $\begin{array}{l}\text { Для руководства научной деятельностью } \\
\text { Карадагской научной станции при МОИП создается } \\
\text { Ученый комитет по делам Карадагской научной } \\
\text { станции под председательством вице-президента } \\
\text { академика А.П. Павлова, место которого занял } \\
\text { проф. Д.В. Соколов. Большое участие в делах } \\
\text { станции принимал президент Общества академик } \\
\text { М.А. Мензбир. } \\
\text { Станция занимает территорию земельного участка, } \\
\text { который был отведен в } 1926 \text { г. Феодосийской } \\
\text { земельной комиссией. Общая площадь } 91 \text { га, среди } \\
\text { них овраги и скалы, частично покрытые древесной } \\
\text { и кустарниковой растительностью. }\end{array}$ & $\begin{array}{l}\text { 1924-1928 гг. Сборы крымских птиц и } \\
\text { млекопитающих сделали К.К. Флеров, } \\
\text { Н.А. Бобринский. Ныне эти сборы - в коллекциях } \\
\text { Зоологического института РАН в Санкт- } \\
\text { Петербурге и Зоомузея МГУ. }\end{array}$ \\
\hline 1927 & $\begin{array}{l}\text { Карадагская научная станция МОИП находится в } \\
\text { периоде полной реорганизации. Меры } \\
\text { реорганизации обсуждаются в Государственном } \\
\text { Ученом Совете и Главнауке на основании } \\
\text { докладной председателя Ученого комитета по } \\
\text { делам станции Д.В. Соколова. } \\
\text { Утверждено «Временное Положение о Карадагской } \\
\text { научной станции в Крыму». }\end{array}$ & $\begin{array}{l}\text { В.Н. Сарандинаки - до } 17.03 .1929 \text { г. временно } \\
\text { исполняла обязанности заведующей станцией. } \\
\text { Изучала наземную флору Карадага, заведовала } \\
\text { библиотекой. }\end{array}$ \\
\hline 1928 & $\begin{array}{l}\text { 29.01.1928. По Постановлению Комитета по делам } \\
\text { Карадагской научной станции МОИП станции } \\
\text { придается значение биологической. } \\
\text { 6.04.1928. Постановлением Научно-технической } \\
\text { секции Государственного Ученого Совета при } \\
\text { Наркомпросе РСФСР и Главнауке РСФСР } \\
\text { Карадагской Научной Станции придан } \\
\text { биологический уклон, т.е. главное внимание } \\
\text { обращено на исследование моря в прилегающих к } \\
\text { Карадагу участков. } \\
\text { 12.08.1928. По предложению научного отдела } \\
\text { Главнауки Карадагская научная станция должна } \\
\text { выработать план работ на ближайшие годы. }\end{array}$ & $\begin{array}{l}\text { Издано: Исторический очерк крымских } \\
\text { землетрясений / А.Ф. Слудский. // Крым. - М.: - } \\
\text { Л. Госиздат, 1928. - № } 1 \text { (5). - Вып. 1. - С.17-24 }\end{array}$ \\
\hline 1929 & $\begin{array}{l}\text { 13.03.1929. Согласно директивам Главнауки от } \\
\text { 6.04.28 г. о придании станции биологического } \\
\text { характера закончено комплектование научного } \\
\text { персонала. Станция стала именоваться Карадагская } \\
\text { биологическая станция (КБС) МОИП. } \\
\text { С октября } 1929 \text { г. КБС переходит в ведение } \\
\text { Наркомпроса Крымской АССР. } \\
\text { С } 1929 \text { г. развернулись исследования морской } \\
\text { фауны и флоры. } \\
\text { Ф.Ю. Левинсон-Лессинг и Е.Н. Дьяконова- } \\
\text { Савельева составили петрографическую карту } \\
\text { Карадага. }\end{array}$ & $\begin{array}{l}\text { Профессор В.Л. Паули - заведующий в период с } \\
1929 \text { г. по 01.06.1933 г. }\end{array}$ \\
\hline 1930 & $\begin{array}{l}\text { КБС МОИП переведена на бюджет Крымского } \\
\text { Народного комиссариата просвещения Крымской } \\
\text { АССР. }\end{array}$ & $\begin{array}{l}\text { Издано: Труды Карадагской научной станции } \\
\text { имени Т.И. Вяземского / Под ред. В.Л. Паули. - } \\
\text { Симферополь: Крымское государственное } \\
\text { издательство, 1930. - Выпуск 3. - } 50 \text { с. }\end{array}$ \\
\hline
\end{tabular}




\begin{tabular}{|c|c|c|}
\hline 1931 & $\begin{array}{l}\text { КБС передана в подчинение Народного } \\
\text { комиссариата просвещения Крымской АССР. } \\
\text { 16.07.1931. Ученый совет КБС принял } \\
\text { постановление о том, чтобы Академия Наук } \\
\text { приняла станцию в качестве своего опорного } \\
\text { пункта в Восточном Крыму для исследований в } \\
\text { области ботаники, зоологии, гидробиологии и пр. }\end{array}$ & $\begin{array}{l}\text { Издано: Труды Карадагской научной станции } \\
\text { имени Т.И. Вяземского / Под ред. В.Л. Паули. - } \\
\text { Симферополь: Крымское государственное } \\
\text { издательство, 1931. - Выпуск 4. - } 228 \text { с. }\end{array}$ \\
\hline 1933 & $\begin{array}{l}\text { КБС была реорганизована в Карадагскую } \\
\text { естественно-научную краеведческую станцию. } \\
\text { Созданы три отдела: географо-геологический, } \\
\text { ботанический, гидробиологический. }\end{array}$ & Заведующий с 1933 г. по 1935 г. - А.Г. Кудин \\
\hline $\begin{array}{r}1934- \\
1936\end{array}$ & $\begin{array}{l}\text { Карадагская естественно-научная станция } \\
\text { Наркомпроса Крымской АССР, бюджетная } \\
\text { принадлежность - республиканская, существует } \\
\text { самостоятельно. }\end{array}$ & Заведующий с 1935 г. по 1936 г. - А.Е. Сайкин \\
\hline 1937 & $\begin{array}{l}\text { 11.06.1937. Постановлением Президиума АН УССР } \\
\text { КБС введена в состав АН УССР и становится } \\
\text { Карадагской биологической станцией АН УССР. } \\
\text { Станция передана АН УССР на основе договора } \\
\text { между Народным комиссариатом Просвещения } \\
\text { Крымской АССР и АН УССР как самостоятельная } \\
\text { единица. } \\
\text { Президиумом АН УССР был организован Ученый } \\
\text { Совет станции под председательством академика } \\
\text { И.И. Шмальгаузена. В его состав вошли академики } \\
\text { А.А. Богомолец, А.В. Палладин, М.Г. Холодный, } \\
\text { А.В. Леонтович и профессора Я.В. Ролл, } \\
\text { В.В. Ковальский, Н.В. Ермаков, А.П. Маркевич и } \\
\text { др. }\end{array}$ & $\begin{array}{l}\text { Доктор биологических наук, профессор } \\
\text { К.А. Виноградов - директор в периоды с } \\
\text { 09.08.1937 г. по 31.12.1937 г. и с } 1940 \text { г. по } 1952 \text { г. } \\
\text { Директором с 1937 г. по 20.08.1939 г. был } \\
\text { И.В. Шаронов }\end{array}$ \\
\hline 1939 & $\begin{array}{l}\text { Создана лаборатория физиологии и биохимии } \\
\text { морских организмов. Впервые на Черном море } \\
\text { начаты работы по изучению химического состава } \\
\text { гидробионтов. }\end{array}$ & $\begin{array}{l}\text { Директор с } 1939 \text { г. по } 1940 \text { г. - профессор } \\
\text { Н.В. Ермаков. } \\
\text { Издано: Труды Карадагской научной станции } \\
\text { имени Т.И. Вяземского / Под ред. } \\
\text { В.А. Водяницкого. - Симферополь: } \\
\text { Государственное издательство Крымской АССР, } \\
\text { 1939. - Выпуск 5. - } 175 \text { с. }\end{array}$ \\
\hline 1940 & $\begin{array}{l}\text { Перед войной станция имела свою электростанцию. } \\
\text { Завершено строительство морского водопровода. }\end{array}$ & $\begin{array}{l}\text { Издано: Труди Карадагської біологічної станції. - } \\
\text { К.: Видавництво Академії наук УССР, 1940. - } \\
\text { Випуск 6. - } 174 \text { с. }\end{array}$ \\
\hline 1941 & $\begin{array}{l}\text { Эвакуация станции была проведена дирекцией КБС } \\
\text { (К.А. Виноградовым) по собственной инициативе и } \\
\text { санкцинирована Судакским райсоветом } \\
\text { трудящихся Крымской АССР, пославшим } \\
5.10 .1941 \text { г. телеграмму Феодосийскому } \\
\text { эвакопункту с соответствующими указаниями. } \\
\text { При угрозе захвата станции немецко-фашистскими } \\
\text { войсками осенью } 1941 \text { г., на основании } \\
\text { распоряжения Судакского райисполкома от } 10 \\
\text { октября } 1941 \text { г., К.А. Виноградов осуществил } \\
\text { эвакуацию станции в Уфу (с } 26.10 .1941 \text { г. по } \\
13.12 .1941 \text { г.). }\end{array}$ & $\begin{array}{l}\text { Крымская группа штаба Розенберга в } 1942 \text { г. взяла } \\
\text { лабораторный корпус в свое ведение, прислав } \\
\text { своего представителя - микробиолога проф. } \\
\text { Шварца. Он и представители штаба Розенберга } \\
\text { Шмидт и Берендт занимались изъятием из } \\
\text { библиотеки станции ценных книг. } \\
\text { Шварц разбил бюст доктора Т.И. Вяземского, } \\
\text { выбросив его с обрыва. }\end{array}$ \\
\hline 1943 & $\begin{array}{l}\text { Имущество станции вместе с АН УССР переведено } \\
\text { в Москву. }\end{array}$ & \\
\hline
\end{tabular}




\begin{tabular}{|c|c|c|}
\hline 1944 & $\begin{array}{l}\text { 12.04.1944. На Карадаг вступили части Советской } \\
\text { отдельной Приморской армии генерала } \\
\text { А.И. Еременко. } \\
\text { 17.06.1944. По распоряжению Совета Народных } \\
\text { Комиссаров УССР № } 810 \text { оборудование и личный } \\
\text { состав реэвакуируются. Постановлением Совета } \\
\text { Народных Комиссаров УССР предусмотрено } \\
\text { восстановление Карадагской биологической } \\
\text { станции в составе Академии наук УССР на прежних } \\
\text { основаниях. } \\
\text { 14.07.1944. Утверждена структура и штаты } \\
\text { Карадагской биологической станции АН УССР } \\
\text { (Протокол № } 10 \text { заседания Президиума АН УССР). } \\
\text { 17.07.1944. Возобновление работы станции после } \\
\text { возвращения из эвакуации. } \\
\text { 31.07.1944. К.А. Виноградову выдан допуск для } \\
\text { восстановления Карадагской научной } \\
\text { биологической станции. } \\
\text { 25.08.1944. Составлен Акт об ущербе, причиненном } \\
\text { немецко-фашистскими захватчиками и их } \\
\text { сообщниками КБС АН УССР в результате } \\
\text { расквартирования на территории Биостанции } \\
\text { вражеских частей в период с } 7 \text { ноября } 1941 \text { г. по } 12 \\
\text { апреля 1944 г. Из 20 зданий и сооружений в } \\
\text { удовлетворительном состоянии осталось только } 2 . \\
\text { Общий ущерб от уничтожения зданий и имущества } \\
\text { составил } 1814 \text { 071 руб. } \\
\text { 6.10.1944. Президиум АН УССР рассмотрел } \\
\text { докладную записку К.А. Виноградова «О состоянии } \\
\text { Карадагской биологической станции Академии } \\
\text { наук УССР и мероприятиях по ее восстановлению» } \\
\text { и принял решение об организации работы на } \\
\text { Карадагской биологической станции (Протокол № } \\
\text { 18). } \\
\text { В докладной записке К.А. Виноградов отмечал: } \\
\text { «необходимо объявление территории станции и } \\
\text { прилегающего к ней района государственным } \\
\text { заповедником, к чему имеется сейчас такой } \\
\text { благоприятствующий этому момент, как } \\
\text { ликвидация колхозной системы в горной части } \\
\text { Крыма, вследствие чего вопрос о закреплении } \\
\text { «навечно» за колхозами земли отпадает». }\end{array}$ & $\begin{array}{l}\text { В архиве станции сохранился проект решения } \\
\text { Президиума Академии наук УССР: обратиться в } \\
\text { Совнарком РСФСР с просьбой объявить } \\
\text { территорию, которая расположена около Станции, } \\
\text { государственным заповедником с геологическим } \\
\text { и ботаническим направлением, но с тем, чтобы } \\
\text { этот заповедник принадлежал в } \\
\text { административном отношении - дирекции } \\
\text { Карадагской Биостанции. }\end{array}$ \\
\hline 1947 & $\begin{array}{l}\text { Карадаг был объявлен Памятником природы } \\
\text { местного значения }\end{array}$ & \\
\hline 1949 & & $\begin{array}{l}\text { Издано: Труды Карадагской биологической } \\
\text { станции. - К.: Издательство Академии наук } \\
\text { УССР, 1949. - Выпуск 7. - } 107 \text { с.; } \\
\text { Труды Карадагской биологической станции. - К.: } \\
\text { Издательство Академии наук УССР, 1949. - } \\
\text { Выпуск 8. - } 84 \text { с. }\end{array}$ \\
\hline 1950 & $\begin{array}{l}\text { 29.05.1950. По решению Президиума АН УССР } \\
\text { КБС передана Институту гидробиологии АН УССР } \\
\text { для общего руководства станцией. Станция } \\
\text { оставлена как отдельная структурная единица, } \\
\text { входящая в Отделение биологических наук с } \\
\text { собственным бюджетом, штатным расписанием и } \\
\text { печатным органом. }\end{array}$ & $\begin{array}{l}\text { Издано: Труды Карадагской биологической } \\
\text { станции. - К.: Издательство Академии наук } \\
\text { УССР, 1950. - Выпуск 9. - } 160 \text { с.; } \\
\text { Труды Карадагской биологической станции. - К.: } \\
\text { Издательство Академии наук УССР, 1950. - } \\
\text { Выпуск 10. - } 149 \text { с. }\end{array}$ \\
\hline 1951 & & $\begin{array}{l}\text { Издано: Труды Карадагской биологической } \\
\text { станции. - К.: Издательство Академии наук } \\
\text { УССР, 1951. - Выпуск 11. - } 141 \text { с. }\end{array}$ \\
\hline
\end{tabular}


31.03.1952. По решению Президиума АН СССР в состав Крымского филиала АН СССР вошла Карадагская станция.

02.04.1952. На основе Постановления Президиума АН УССР (протокол № 11, п. 103) составлен акт сдачи-приема КБС Крымскому филиалу АН УССР. 11.06.1952. КБС передана из АН УССР в АН СССР. По распоряжению Крымского филиала АН СССР КБС перешла в его состав и стала называться Карадагская биологическая станция Крымского филиала АН СССР, что привело к изменению профиля работы станции.

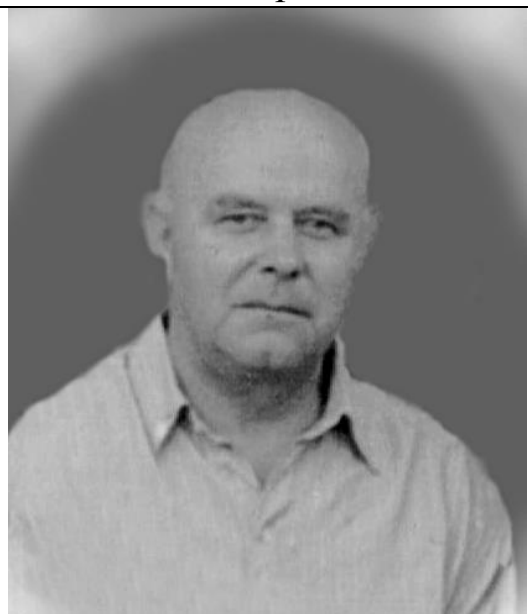

Кандидат биологических наук Г.П. Трифонов Врио директора с 15.07.1952 г. по 10.10.1953 г. и с 27.08.1955 г. по март 1956 г.

Издано: Труды Карадагской биологической станции. - К.: Издательство Академии наук УССР, 1952. - Выпуск 12. - 136 с.

Директор с 03.10.1953 г. по 27.08.1955 г. -
А.С. Лещинская.

Издано: Трифонов Г.П. Рыбоводство в пресных водоемах Крыма. - Симферополь: Крымиздат, 1954. -52 c.

25.06.1954 г. о приеме в состав АН УССР

Крымского филиала АН СССР станция вновь стала работать в системе Украинской академии наук и называться Карадагская биологическая станция АН УССР.

\begin{tabular}{|c|c|c|}
\hline 1955 & & $\begin{array}{l}\text { Директор - Г.П. Трифонов. } \\
\text { Издано: Труды Карадагской биологической } \\
\text { станции. - Симферополь.: Крымиздат, 1955. - } \\
\text { Выпуск 13. - } 193 \text { с. }\end{array}$ \\
\hline 1956 & $\begin{array}{l}\text { 6.07.1956. Постановление Президиума АН УССР, } \\
\text { протокол № 42, п. } 507 \text { о реорганизации Крымского } \\
\text { филиала АН УССР в соответствии с } \\
\text { постановлением Совета Министров УССР от } \\
27.06 .1956 \text { г. о подчинении Карадагской } \\
\text { биологической станции прежнего Крымского } \\
\text { филиала АН УССР непосредственно Президиуму } \\
\text { АН УССР. КБС подчинили Отделу биологических } \\
\text { наук на правах отдельного научно- } \\
\text { исследовательского учреждения. } \\
\text { 20.09.1956. На Бюро Отделения биологических наук } \\
\text { Президиума АН УССР рассмотрен вопрос о } \\
\text { направлении научно-исследовательских работ и о } \\
\text { мерах помощи Карадагской биологической станции, } \\
\text { а также развитии экспериментальных исследований } \\
\text { на базе Карадагской станции. } \\
\text { Организована гидрохимическая лаборатория. } \\
\text { Начало строительства экспериментального } \\
\text { бассейна. }\end{array}$ & $\begin{array}{l}\text { Доктор биологических наук А.Н. Смирнов - } \\
\text { директор с марта } 1956 \text { г. по 06.07.1959 г. }\end{array}$ \\
\hline 1957 & $\begin{array}{l}\text { Проведена линия морского водопровода. } \\
\text { Приобретены моторный катер и моторная лодка. }\end{array}$ & $\begin{array}{l}\text { Исследования по гидрохимии, изучение фито-, } \\
\text { зоопланктона, ихтиофауны, жизненных циклов и } \\
\text { поведения рыб. Изучение геологии Карадага. } \\
\text { Издано: Труды Карадагской биологической } \\
\text { станции. - К.: Издательство Академии наук } \\
\text { УССР, 1957. - Выпуск 14. - } 160 \text { с. }\end{array}$ \\
\hline
\end{tabular}




\begin{tabular}{|c|c|c|}
\hline 1958 & $\begin{array}{l}\text { Построен магазин и хозяйственный склад. На месте } \\
\text { котлована, заложенного Т.И. Вяземским, достроен } \\
\text { большой морской бассейн-аквариум. }\end{array}$ & \\
\hline 1959 & $\begin{array}{l}\text { Директор А.Н. Смирнов считал необходимым } \\
\text { срочно поставить вопрос перед правительством } \\
\text { УССР о превращении Карадага в заповедный } \\
\text { участок (около } 1500 \text { га) и об охране его природы. } \\
\text { Границей заповедного участка является весь район } \\
\text { от пос. Планерского, затем по судакскому шоссе до } \\
\text { Отузской долины, далее по Отузской долине до } \\
\text { КБС (до моря). С юга и юго-востока границей } \\
\text { является морское побережье. } \\
\text { Под руководством директора В.Д. Гордеева было } \\
\text { организовано строительство жилых домов для } \\
\text { сотрудников станции, ремонт разрушенных зданий, } \\
\text { проведена дорога из п. Курортного на биостанцию. }\end{array}$ & $\begin{array}{l}\text { Кандидат технических наук В.Д. Гордеев - } \\
\text { директор с 03.10.1959 г. по 01.10.1963 г. } \\
\text { Издано: «Карадаг: научно-популярные очерки» / } \\
\text { А.Н. Смирнов и др. / АН УССР. - Киев. }\end{array}$ \\
\hline 1960 & & $\begin{array}{l}\text { Издано: Труды Карадагской биологической } \\
\text { станции. - К.: Издательство Академии наук } \\
\text { УССР, 1960. - Выпуск 16. - } 169 \text { с. }\end{array}$ \\
\hline 1961 & & $\begin{array}{l}\text { Издано: Труды Карадагской биологической } \\
\text { станции. - К.: Издательство Академии наук } \\
\text { УССР, 1961. - Выпуск 17. - } 125 \text { с. }\end{array}$ \\
\hline 1962 & & $\begin{array}{l}\text { Издано: Труды Карадагской биологической } \\
\text { станции. - К.: Издательство Академии наук } \\
\text { УССР, 1962. - Выпуск 18. - } 92 \text { с. }\end{array}$ \\
\hline 1963 & $\begin{array}{l}\text { 11.07.1963. Постановление Совета Министров } \\
\text { УССР № } 796 \text { об организации в составе АН УССР } \\
\text { Института биологии южных морей на базе } \\
\text { Севастопольской, Карадагской и Одесской } \\
\text { биологической станций. } \\
\text { 25.07.1963. КБС была реорганизована в Карадагское } \\
\text { отделение Института биологии южных морей АН } \\
\text { УССР им. А.О. Ковалевского. } \\
\text { Организация лаборатории фотосинтеза. Начало } \\
\text { исследований физиологии диатомовых водорослей. } \\
\text { о7.08.1963. Распоряжением Совета Министров } \\
\text { УССР № 1180-р территория Карадага была } \\
\text { объявлена Памятником природы республиканского } \\
\text { значения. }\end{array}$ & $\begin{array}{l}\text { Кандидат биологических наук Д.В. Гирник - } \\
\text { руководитель Карадагского отделения с } \\
\text { 1.10.1963 г. по 25.05.1966 г. }\end{array}$ \\
\hline
\end{tabular}


Решением Президиума АН УССР создана лаборатория биоакустики морских животных. Начало исследований эхолокационного аппарата и поведения морских млекопитающих.

Созданы лаборатории ихтиологии, фотосинтеза, биохимии.

В.А. Чепурнов считал, что необходимо Карадаг объявить заповедником.
29.07.1969. Распоряжение Президиума АН УССР № 997 об утверждении проектного задания на строительство экспериментальной базы Карадагского отделения Института биологии южных морей - дельфинария.

08.07.1970. Распоряжение Крымоблисполкома № 660-р о начале работ по организации комплексного государственного заповедника Карадаг: получение разрешения на проектноизыскательские работы, подготовка предварительной схемы государственного заповедника.

1972 Начало строительства первой очереди экспериментальной базы КО ИнБЮМ. 18.04.1972. Карадагскому отделению ИнБЮМ выдан Акт на право пользования землей $(\mathrm{S}=34,91$ га).

1976 15.10.1976. По Постановлению Президиума АН УССР № 310 утверждено строительство второй очереди экспериментальной базы на Карадаге.

1977 Комиссия, назначенная Президиумом АН УССР (Распоряжение № 110 от 20.01.1977 г.) приняла в эксплуатацию законченное строительство Карадагского научно-исследовательского комплекса Института биологии южных морей АН УССР им. А.О. Ковалевского. Создана лаборатория биоакустики и этологии.

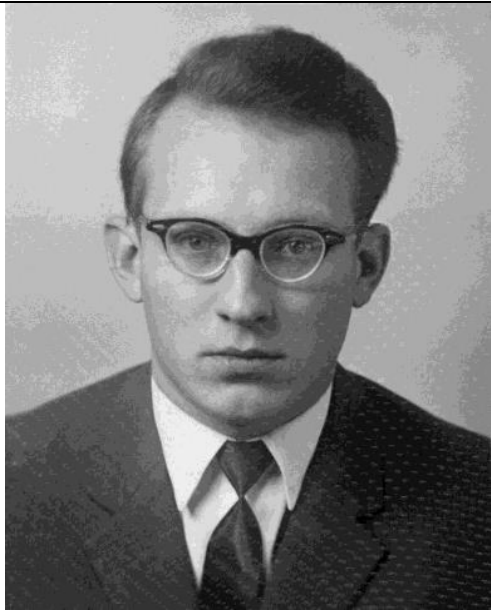

Кандидат биологических наук А.В. Чепурнов руководитель Карадагского отделения с 23.05.1966 г. по 30.09.1969 г.

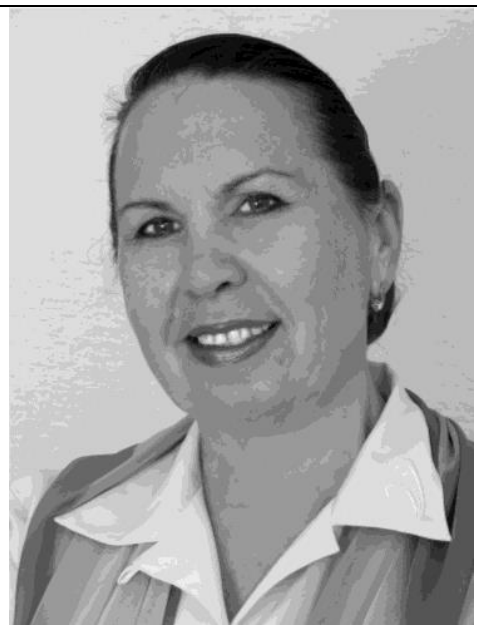

Кандидат биологических наук А.Л. Морозова руководитель Карадагского отделения с 01.10.1969 г. по 21.04.1982 г., директор Карадагского природного заповедника с 14.07.1999 г. по 31.08.2015 г. 


\begin{tabular}{|c|c|c|}
\hline 1979 & $\begin{array}{l}\text { 09.08.1979. Постановлением Совета Министров } \\
\text { УССР № } 386 \text { был организован Карадагский } \\
\text { государственный заповедник в системе Академии } \\
\text { наук УССР общей площадью } 3 \text { тыс. га. } \\
\text { 21.08.1979. Приказ № } 134 \text { Государственного } \\
\text { комитета Совета Министров УССР по охране } \\
\text { природы «Об организации Карадагского } \\
\text { государственного заповедника». } \\
\text { 30.08.1979. Распоряжение Президиума АН УССР } \\
\text { № } 1506 \text { «Об организации Карадагского } \\
\text { заповедника». }\end{array}$ & $\begin{array}{l}\text { Утверждение в должности директора } \\
\text { Карадагского государственного заповедника } \\
\text { Л.Г. Коваленко в период с } 1.10 .1979 \text { г. по } \\
30.11 .1981 \text { г. } \\
\text { Утверждение плана комплексных научно- } \\
\text { исследовательских работ Карадагскго } \\
\text { государственного заповедника АН УССР на 1980- } \\
1985 \text { гг. }\end{array}$ \\
\hline 1980 & $\begin{array}{l}\text { 10.12.1980. Постановление АН УССР № } 569 \text { «Об } \\
\text { организации научной деятельности Карадагского } \\
\text { государственного заповедника АН УССР». } \\
\text { Карадагскому государственному заповеднику } \\
\text { выдан Государственный Акт на право пользования } \\
\text { землей (1369,9 га суши и } 600 \text { га акватории моря) - } \\
\text { первая очередь земель. }\end{array}$ & $\begin{array}{l}\text { Заповедник входил в состав КО ИнБЮМ на } \\
\text { правах структурного подразделения. }\end{array}$ \\
\hline 1981 & $\begin{array}{l}\text { Утверждено Положение о Карадагском } \\
\text { государственном заповеднике АН УССР. }\end{array}$ & $\begin{array}{l}\text { Издано: Згуровская Л.Н. Рассказы о деревьях } \\
\text { Крыма: Краеведческие очерки. - Симферополь: } \\
\text { Таврия, 1981. - } 192 \text { с. }\end{array}$ \\
\hline 1982 & $\begin{array}{l}\text { Утверждено Положение об охранной зоне } \\
\text { Карадагского государственного заповедника } \\
\text { (площадь - 20,9 га). } \\
\text { 5.10.1982. Решение Исполкома Крымского } \\
\text { областного совета народных депутатов «Об отводе } \\
\text { Карадагскому государственному заповеднику АН } \\
\text { УССР земельных участков общей площадью } \\
\text { 1485,21 га из землепользования Судакского района } \\
\text { для расширения его заповедных территорий и } \\
\text { установления охранных зон заповедника» }\end{array}$ & $\begin{array}{l}\text { Кандидат биологических наук В.Н. Дубонос - } \\
\text { руководитель отделения с апреля } 1982 \text { г. по } \\
21.08 .1982 \text { г. } \\
\text { Кандидат биологических наук В.Л. Черепнов - } \\
\text { руководитель отделения с августа } 1982 \text { г. по } \\
01.12 .1983 \text { г. }\end{array}$ \\
\hline 1983 & $\begin{array}{l}\text { Комплексная экспедиция Украинского } \\
\text { лесоустроительного предприятия осуществила } \\
\text { лесоустройство территории Карадагского } \\
\text { государственного заповедника. } \\
\text { Подготовлены следующие документы: } \\
\text { - План типов леса Карадагского государственного } \\
\text { заповедника; } \\
\text { - Почвенно-лесотипологический очерк } \\
\text { Карадагского государственного заповедника АН } \\
\text { УССР; } \\
\text { - Карта размещения научных стационаров } \\
\text { Карадагского государственного заповедника АН } \\
\text { УССР; } \\
\text { - Карта болезней и очагов вредителей Карадагского } \\
\text { государственного заповедника АН УССР; } \\
\text { - План лесонасаждений и акватории Карадагского } \\
\text { государственного заповедника АН УССР. } \\
\text { Украинским лесоустроительным предприятием } \\
\text { подготовлен «Проект организации и развития } \\
\text { лесного хозяйства Карадагского государственного } \\
\text { заповедника АН УССР Крымской области». }\end{array}$ & $\begin{array}{l}\text { Кандидат биологических наук П.Г. Семеньков - } \\
\text { руководитель отделения с 01.12.1983 г. по } \\
\text { 04.10.1986 г. и с } 16.11 .1989 \text { г. по 02.07.1997 г. }\end{array}$ \\
\hline 1984 & $\begin{array}{l}\text { Выдан Государственный Акт на право пользования } \\
\text { землей (S=2855,11 га) - вторая очередь земель. } \\
\text { Подготовлены геоботанический очерк Карадагского } \\
\text { государственного заповедника АН УССР, } \\
\text { геоботанический план Карадагского } \\
\text { государственного заповедника АН УССР, очерк } \\
\text { донной растительности Карадагского } \\
\text { государственного заповедника АН УССР. } \\
\text { Составлены паспорта постоянных пробных } \\
\text { площадей. }\end{array}$ & \\
\hline
\end{tabular}


Постановление Президиума АН УССР о создании в Карадагском заповеднике автоматической системы мониторинга окружающей среды с широкими возможностями получения разнообразной информации.

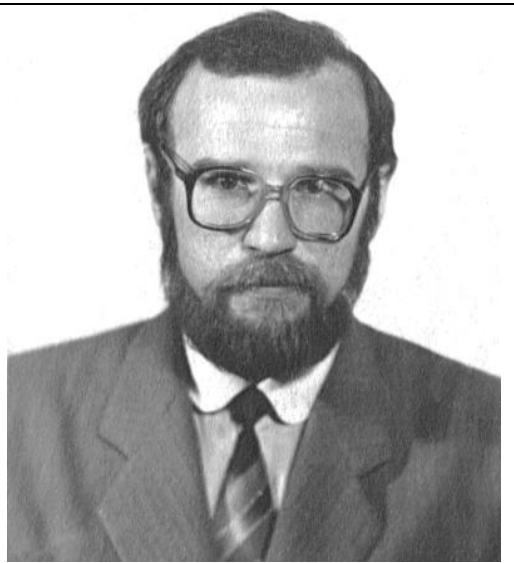

Кандидат биологических наук А.А. Вронский руководитель отделения с 04.10.1986 г. по 16.11.1989 г, директор Карадагского природного заповедника с 08.07.1998 г. по 14.07.1999 г.

Издано: Згуровская Л.Н. Карадаг. Времена года. Симферополь: Таврия. - 1987. - 224 с.

1988 20.04.1988. Постановлением АН УССР № 170

КО ИнБЮМ переименовано в Карадагский филиал ИнБЮМ им. А.О. Ковалевского.

Государственному заповеднику Карадагского отделения ИнБЮМ выдан Государственный Акт на право пользования землей ( $\mathrm{S}=2065,07$ га).

Утверждено «Положение о Карадагском филиале Института биологии южных морей АН УССР». В состав филиала входит и Карадагской государственный заповедник.
Изданы монографии: Природа Карадага /

Бескаравайный М.М., Костенко Н.С.,

Миронова Л.П. и др.; Под ред. Морозовой А.Л. и

Вронского А.А. - К.: Наук. думка, 1989. - 288 с.;

Вронский А.А., Николайчук Л.А.

Функциональная морфология осевой локомоторной мускулатуры костистых рыб / Отв. ред. Мельник К.П. - К.: Наук. думка, 1989. $184 \mathrm{c.}$

Издано: Ефетов К.А., Будашкин Ю.И. Бабочки Крыма (Высшие разноусые чешуекрылые): Справ. - Симферополь: Таврия, 1990. - 112 с.

Издано: монографии Довгаль Ю.М.,

Радзивил В.Я., Токовенко В.С., Чернявский С.В., Михалёнок Д.К. Вулканы Карадага / отв. ред. Науменко В.В. - К.: Наук. Думка, 1991. - 104 с.; Кустенко Н.Г. Влияние стрессовых факторов на размножение диатомовых водорослей / Отв. ред. Максимов В.Н. - К.: Наук. думка, 1991. - 156 с.

1992 24.12.1992. Распоряжением № 1118 Президиума АН Украины Карадагский государственный заповедник переименован в «Карадагский природный заповедник Академии наук Украины». Указом Президента Украины от 22 марта 1994 г. Академия наук Украины переименована в Национальную академию наук Украины, Постановление Общего собрания АН Украины от 23 марта 1994 г. 


\begin{tabular}{|c|c|c|}
\hline 1997 & $\begin{array}{l}\text { 14.05.1997. Постановление № } 182 \text { Президиума } \\
\text { НАНУ «О придании статуса юридического лица } \\
\text { Карадагскому природному заповеднику». } \\
\text { Заповедник является правопреемником } \\
\text { Карадагского филиала ИнБЮМ. Реорганизовать } \\
\text { Карадагский филиал ИнБЮМ в биостанцию } \\
\text { ИнБЮМ на правах научного подразделения } \\
\text { заповедника. Подчинить Карадагский природный } \\
\text { заповедник НАНУ Отделению общей биологии } \\
\text { НАНУ } \\
\text { 13.06.1997. Решением Феодосийского городского } \\
\text { совета народных депутатов зарегистрирован } \\
\text { Карадагский природный заповедник НАНУ, его } \\
\text { устав. }\end{array}$ & $\begin{array}{l}\text { Доктор геолого-минералогических наук } \\
\text { В.А. Емельянов - директор Карадагского } \\
\text { природного заповедника с 14.05.1997 г. по } \\
27.04 .1998 \text { г. } \\
\text { Издано: Труды Карадагского филиала Института } \\
\text { биологии южных морей им. А.О. Ковалевского } \\
\text { НАН Украины: Сб. научн. тр. / Под ред. } \\
\text { Н.А. Давидовича, В.А. Емельянова. - } \\
\text { Севастополь, 1997. - 224 с.; } \\
\text { Курорт Коктебель / Под ред. к.б.н. } \\
\text { А.А. Вронского. - К.: Наукова думка, 1997. - } 136 \\
\text { с.; }\end{array}$ \\
\hline 1998 & $\begin{array}{l}\text { 10.02.1998. Утверждено Положение о Карадагском } \\
\text { природном заповеднике Национальной академии } \\
\text { наук Украины. }\end{array}$ & $\begin{array}{l}\text { Кандидат биологических наук Ю.И. Будашкин - } \\
\text { директор с 27.04.1998 г. по 08.07.1998 г. }\end{array}$ \\
\hline 1999 & & $\begin{array}{l}\text { Издано: Ландшафтно-экологический стационар } \\
\text { Карадагского природного заповедника. Вып. 1/ } \\
\text { Под ред. А.Л. Морозовой, Ю.И. Будашкина, } \\
\text { В.А. Бокова. - Симферополь: Таврия-Плюс, } 1999 . \\
\text { - } 110 \text { с.; } \\
\text { Михаленок Д.К. Карадагский калейдоскоп. } \\
\text { Калейдоскоп литературы, науки, искусства. } \\
\text { Версия 1. - Симферополь: Таврия, 1999. - } 390 \text { с.; } \\
\text { Юго-восточный Крым: Лисья бухта - Эчки-Даг. } \\
\text { Справочное издание / Под ред. к.б.н. } \\
\text { А.А. Вронского и к.б.н. Л.П. Мироновой. - } \\
\text { Севастополь, 1999. - } 119 \text { с. }\end{array}$ \\
\hline 2000 & $\begin{array}{l}\text { 09.08.2000. Приказом Министерства экологии и } \\
\text { природных ресурсов Украины научным куратором } \\
\text { Карадаского природного заповедника НАНУ } \\
\text { утвержден Институт биологии южных морей НАНУ } \\
\text { им. А.О. Ковалевского. }\end{array}$ & \\
\hline 2001 & $\begin{array}{l}\text { 19.12.2001. Постановлением Кабинета министров } \\
\text { Украины № } 1709 \text { «Растительно-животный комплекс } \\
\text { Карадагского природного заповедника и фонд } \\
\text { старопечатных книг (XVII-ХІХ ст.) библиотеки } \\
\text { заповедника» (Феодосийский район, АРК) внесены } \\
\text { в Государственный реестр научных объектов } \\
\text { национального достояния Украины (Свидетельство } \\
\text { от } 19 \text { февраля } 2009 \text { г.) № } 52 .\end{array}$ & $\begin{array}{l}\text { Издано: Карадаг. История, биология, археология } \\
\text { (Сборник научных трудов, посвящённый 85- } \\
\text { летию Карадагской биологической станции им. } \\
\text { Т.И. Вяземского) / Под ред. А.Л. Морозовой, } \\
\text { В.Ф. Гнюбкина. - Симферополь: СОНАТ, 2001. - } \\
304 \text { с. }\end{array}$ \\
\hline
\end{tabular}




\begin{tabular}{|c|c|c|}
\hline 2004 & $\begin{array}{l}\text { «Аквально-скальный комплекс Карадага» объявлен } \\
\text { водно-болотным угодьем международного значения } \\
\text { (Рамсарская конвенция), № } 1394 . \\
\text { 05-06.10.2004 - юбилейная сессия научно- } \\
\text { технического Совета Карадагского природного } \\
\text { заповедника НАНУ, посвященная 90-летию } \\
\text { Карадагской научной станции им. Т.И. Вяземского } \\
\text { и 25-летию Карадагского природного заповедника. } \\
\text { С докладами выступили ведущие ученые Украины } \\
\text { и России. }\end{array}$ & $\begin{array}{l}\text { Издано: Карадаг. История, геология, ботаника, } \\
\text { зоология (Сборник научных трудов, посвящённый } \\
\text { 90-летию Карадагской научной станции им. } \\
\text { Т.И. Вяземского и 25-летию Карадагского } \\
\text { природного заповедника НАН Украины). Книга 1- } \\
\text { я. / Под ред. А.Л. Морозовой, В.Ф. Гнюбкина. - } \\
\text { Симферополь: СОНАТ, 2004. - } 464 \text { с. } \\
\text { Карадаг. Гидробиологические исследования } \\
\text { (Сборник научных трудов, посвящённый 90- } \\
\text { летию Карадагской научной станции им. } \\
\text { Т.И. Вяземского и 25-летию Карадагского } \\
\text { природного заповедника НАН Украины). Книга 2- } \\
\text { я. / Под ред. А.Л. Морозовой, В.Ф. Гнюбкина. - } \\
\text { Симферополь: СОНАТ, 2004. - 500 с.; } \\
\text { Бабушина Е.С. Пока улыбается дельфин. - } \\
\text { Симферополь: Бизнес-Информ, } 2002 . \text { - } 64 \text { с.; } \\
\text { Летопись природы. Том ХХ. } 2003 \text { г. / Под ред. } \\
\text { к.б.н. Ю.И. Будашкина. - Симферополь: СОНАТ, } \\
\text { 2004. - } 244 \text { с. }\end{array}$ \\
\hline 2005 & $\begin{array}{l}\text { Утвержден «Проект организации территории и } \\
\text { охраны природных комплексов Карадагского } \\
\text { природного заповедника НАН Украины» }\end{array}$ & $\begin{array}{l}\text { Издано: Слудский Е.А. Карадаг. Воспоминания } \\
\text { (1917-1926 гг.). - Симферополь: СОНАТ, } 2004 \text { - } \\
\text { 2005. - } 112 \text { с.; } \\
\text { Костенко Н.С., Шатко В.Г., Бескаравайный М.М., } \\
\text { Будашкин Ю.И., Каменских Л.Н., Кукушкин О.В. } \\
\text { В царстве древнего вулкана. Карадаг. } \\
\text { Фотоальбом. - Симферополь: СОНАТ, } 2004 \text { - } \\
\text { 2005. - } 192 \text { с. }\end{array}$ \\
\hline 2006 & & $\begin{array}{l}\text { Издано: Карадаг. } 90 \text { лет Карадагской научной } \\
\text { станции имени Т.И. Вяземского и } 25 \text { лет } \\
\text { Карадагскому природному заповеднику. } \\
\text { Материалы юбилейной сессии, научно- } \\
\text { технического совета, } 2004 \text { год. - Симферополь, } \\
\text { СОНАТ, 2006. - } 104 \text { с.; } \\
\text { Летопись природы. Том ХХІ. } 2004 \text { г. / Под ред. } \\
\text { к.б.н. А.Л. Морозовой, В.Ф. Гнюбкина. - } \\
\text { Симферополь: СОНАТ, 2006. - } 256 \text { с. }\end{array}$ \\
\hline 2007 & $\begin{array}{l}150 \text { лет со дня рождения Т.И. Вяземского - } \\
\text { основателя Карадагской научной станции. } \\
\text { «Укрпочтой» выпущен конверт с изображением } \\
\text { Т.И. Вяземского, на административной территории } \\
\text { заповедника осуществлено спецгашение. }\end{array}$ & $\begin{array}{l}\text { Издано: Заповедный Карадаг. Очерк- } \\
\text { путеводитель. Серия: Новый крымский } \\
\text { путеводитель. - Симферополь: СОНАТ, 2007. - } \\
320 \text { с.; } \\
\text { Аппак Б., Багрикова Н., Бескаравайный М., } \\
\text { Костин С., Осипова М., Паршинцев А., } \\
\text { Першин О., Семёнов Ю., Цвелых А. Знакомьтесь: } \\
\text { грифы. - К.: Изд-во СПД Кудлюк И.А., 2007. - } 56 \\
\text { с.; } \\
\text { Летопись природы. Том ХХІІ. } 2005 \text { г. / Под ред. } \\
\text { к.б.н. А.Л. Морозовой. - Симферополь: СОНАТ, } \\
\text { 2007. - } 312 \text { с.; } \\
\text { Александр Федорович Слудский. Библиогр. справ. } \\
\text { Вып. 2. - Сост. Ж.К. Владимирова и др. - } \\
\text { Симферополь: Крымский архив, 2007. - } 100 \text { с. }\end{array}$ \\
\hline
\end{tabular}




\begin{tabular}{|c|c|c|}
\hline 2008 & $\begin{array}{l}\text { Получение Государственного акта на право } \\
\text { постоянного пользования земельным участком } \\
\text { Серия ЯЯ № 000865, выданного «Карадагскому } \\
\text { природному заповеднику Национальной академии } \\
\text { наук Украины» на основе Постановления Совета } \\
\text { Министров Автономной Республики Крым от } \\
11.12 .2006 \text { г., № } 808 \text { на площадь 2065,07 га. } \\
\text { Утверждена новая редакция Устава Карадагского } \\
\text { природного заповедника НАНУ. }\end{array}$ & $\begin{array}{l}\text { Издано: Ковблюк Н.М., Кукушкин О.В., } \\
\text { Гнелица В.А., Надольный А.А. Краткий атлас } \\
\text { пауков (Аrachnida, Aranei) Карадагского } \\
\text { природного заповедника. - Симферополь: } \\
\text { Н. Оріанда, 2008. - } 120 \text { с.; } \\
\text { Бескаравайный М.М. Птицы морских берегов } \\
\text { южного Крыма.- Симферополь: Н. Оріанда, } 2008 . \\
\text { - } 160 \text { с.; } \\
\text { Каталог старопечатных изданий. Русские книги } \\
\text { гражданской печати (1760-1985) библиотеки } \\
\text { Т.И. Вяземского / авт.-сост.: Д.К. Михалёнок, } \\
\text { В.Ю. Лапченко, Л.А. Веселовская, О.А. Акимова; } \\
\text { отв. ред. И.Ю. Фоменко. - Севастополь: ЭКОСИ- } \\
\text { Гидрофизика, 2008. - 216 с.; } \\
\text { «Атлас моллюсков Карадага. Хитоны и } \\
\text { Брюхоногие» / В.В. Анистратенко, О.Ю. } \\
\text { Анистратенко, Н.С. Костенко - Симферополь; } \\
\text { Летопись природы. Том ХХІІ. 2006 г. / Под ред. } \\
\text { к.б.н. А.Л. Морозовой. - Симферополь: } \\
\text { Н. Оріанда, 2008. - 420 с.; } \\
\text { Феодосия / Под ред. д.и.н. Э.Б. Петрова. - } \\
\text { Феодосия: ЧерноморПРЕСС, 2008. }\end{array}$ \\
\hline 2009 & $\begin{array}{l}\text { Распоряжение Президиума НАНУ о 95-летии } \\
\text { Карадагской научной станции им. Т.И. Вяземского. } \\
\text { Проведение расширенного заседания Научно- } \\
\text { технического Совета Карадагского природного } \\
\text { заповедника НАНУ и Отделения общей биологии } \\
\text { НАНУ, посвященного 95-летию Карадагской } \\
\text { научной станции. }\end{array}$ & $\begin{array}{l}\text { Издано: Виноградов А.К. Морской биолог } \\
\text { Константин Александрович Виноградов. - } \\
\text { Севастополь: НПЦ «ЭКОСИ-Гидрофизика», } 2009 . \\
\text { - } 105 \text { с.; } \\
\text { Карадаг - 2009: Сборник научных трудов, } \\
\text { посвящённый 95-летию Карадагской научной } \\
\text { станции и 30-летию Карадагского природного } \\
\text { заповедника Национальной академии наук } \\
\text { Украины / Ред. А.В. Гаевская, А.Л. Морозова. - } \\
\text { Севастополь: ЭКОСИ-Гидрофизика, 2009. - } 575 \\
\text { с.; } \\
\text { Летопись природы. Том ХХІV. } 2007 \text { год / Под ред. } \\
\text { к.б.н. А.Л. Морозовой. - Симферополь: } \\
\text { Н. Оріанда, 2009. - 272 с. }\end{array}$ \\
\hline 2010 & & $\begin{array}{l}\text { Издано: Летопись природы. Том XXV. } 2008 \text { год / } \\
\text { Под ред. к.б.н. А.Л. Морозовой. - Симферополь: } \\
\text { Н. Оріанда, 2010. - } 320 \text { с.; }\end{array}$ \\
\hline 2011 & & $\begin{array}{l}\text { Издано: Карадаг заповедный: научно-популярные } \\
\text { очерки / Под ред. А.Л. Морозовой. - } \\
\text { Симферополь: Н.Оріанда, 2011. - } 288 \text { с. } \\
\text { Книга удостоена диплома АРК. }\end{array}$ \\
\hline 2012 & $\begin{array}{l}\text { Утвержден паспорт Водно-болотного угодья } \\
\text { международного значения «Аквально-скальный } \\
\text { комплекс Карадага». }\end{array}$ & $\begin{array}{l}\text { Издано: Бескаравайный М.М. Птицы Крымского } \\
\text { полуострова. - Симферополь: Бизнес-Информ, } \\
\text { 2012. - } 336 \text { с. Книга удостоена премии АР Крым в } \\
\text { номинации «Научная и научно-техническая } \\
\text { деятельность»; } \\
\text { Фіторізноманіття заповідників і національних } \\
\text { природних парків України. 4.1. Біосферні } \\
\text { заповідники. Природні заповідники / Колектив } \\
\text { авторів під ред. В.А. Онищенка і Т.Л. Андрієнко. - } \\
\text { Київ: Фітосоціоцентр, 2012. - } 406 \text { с. }\end{array}$ \\
\hline 2013 & $\begin{array}{l}\text { Утверждено Положение о Карадагском природном } \\
\text { заповеднике НАНУ. } \\
\text { 19.11.2013. Постановление Верховной Рады } \\
\text { Украины № 696-VIII «О праздновании 100-летия со } \\
\text { дня образования Карадагской биологической } \\
\text { станции - Карадагского природного заповедника } \\
\text { НАН Украины». }\end{array}$ & $\begin{array}{l}\text { Издано: Савчук В.В. Атлас бабочек и гусениц } \\
\text { Крыма. - Симферополь: Бизнес-Информ, 2013. - } \\
296 \text { с., цв. илл. }\end{array}$ \\
\hline
\end{tabular}


2014 21.03.2014. Принятие Федерального конституционного закона от 21 марта 2014 г. № 6ФКЗ «О принятии в Российскую Федерацию Республики Крым и образование в составе Российской Федерации новых субъектов - Республики Крым и города Федерального значения Севастополя». 24.03.2014. Карадагский природный заповедник номинировался в Совете Европы на получение Европейского диплома для природоохранных территорий.

9.09.2014. Постановление Госсовета Республики Крым об отнесении Карадагского природного заповедника Национальной академии наук Украины к ведению Государственного комитета по лесному и охотничьему хозяйству Республики Крым.

23.09.2014. Расширенное заседание научнотехнического совета Карадагского природного заповедника, посвященное 100 -летию Карадагской научной станции им. Т.И. Вяземского. Отмечено, что КНС вернулась на историческую родину - в Россию. Сотрудникам вручены почетные грамоты.

8.12.2014. Согласно приказа Государственного комитета по лесному и охотничьему хозяйству Республики Крым № 135 «О приведении устава Карадагского природного заповедника НАН Украины в соответствие с законодательством Российской Федерации и включении в ЕГРЮЛ» учреждение перерегистрировано под названием Государственное бюджетное учреждение науки и охраны природы Республики Крым «Карадагский природный заповедник».

Утвержден устав ГБУ НОП РК «Карадагский природный заповедник».

30.02.2015. Распоряжением Совета Министров Республики Крым № 48-р «О внесении изменений в распоряжение Совета министров Республики Крым от 2 сентября 2014 г. № 867-р закрепляется подчинение Государственного бюджетного учреждения науки и охраны природы Республики Крым «Карадагский природный заповедник» Государственному Комитету по лесному и охотничьему хозяйству Республики Крым, который осуществляет функции учредителя.

7.09.2015. Распоряжение Правительства Российской Федерации № 1743-р о создании Федерального государственного бюджетного учреждения науки «Карадагская научная станция им. Т.И. Вяземского - природный заповедник РАН».
Издано: монография Природа Восточного Крыма. Оценка биоразнообразия и разработка проекта локальной экологической сети / [отв. ред. д.б.н. С.П. Иванов]. - К.: Изд-во, 2013. - 272 е., 25 ил.., 54 табл., 326 библ.;

Мальцев В., Карпова Г., Зуб Л. Крым

заповедный. Туристический путеводитель. Симферополь, 2014. - 96 с.;

брошюра Костенко Н.С. Удивительный и таинственный Карадаг. К 100-летию Карадагской научной станции им. Т.И. Вяземского. Симферополь: Н.Оріанда, 2014. - 88 с.

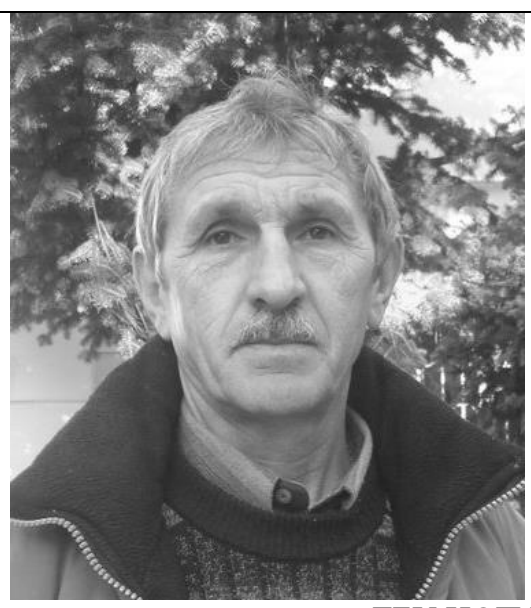

А.Д. Дашкевич - и.о. директора ГБУ НОП РК «Карадагский природный заповедник» с 01.09.2015 г. - по настоящее время.

Издано: 100 лет Карадагской научной станции им. Т.И. Вяземского: сборник научных трудов / Ред. А.В. Гаевская, А.Л. Морозова. - Симферополь: Н.Оріанда, 2015. - 768 с.;

Красная книга Республики Крым. Растения, водоросли и грибы/ Отв. ред. д.б.н., проф.

А.В. Ена и к.б.н. А.В. Фатерыга. - Симферополь: ООО «ИТ «АРИАП», 2015. - 480 с.;

Красная книга Республики Крым. Животные / Отв. ред. д.б.н., проф. С.П. Иванов и к.б.н. А.В. Фатерыга. - Симферополь: ООО «ИТ «АРИАЛ», 2015. - 440 с.. 


\begin{tabular}{|c|c|c|}
\hline 2015 & $\begin{array}{l}\text { 01.12.2015. Приказом ФАНО России № } 580 \\
\text { утвержден устав федерального государственного } \\
\text { бюджетного учреждения науки «Карадагская } \\
\text { научная станция им. Т.И.Вяземского - природный } \\
\text { заповедник РАН». }\end{array}$ & 6 \\
\hline 2016 & $\begin{array}{l}\text { 20.01.2016. Создан Ученый Совет станции. } \\
\text { Председатель - кандидат географических наук } \\
\text { Р.В. Горбунов. } \\
\text { Создан печатный орган станции «Труды } \\
\text { Карадагской научной станции им. Т.И. Вяземского } \\
\text { - природного заповедника РАН» } \\
\text { 23. 08. 2016. Распоряжение Совета Министров } \\
\text { Республики Крым № 977-р «О безвозмездной } \\
\text { передаче имущества из государственной } \\
\text { собственности Республики Крым в федеральную } \\
\text { собственность» }\end{array}$ & $\begin{array}{l}\text { Кандидат географических наук Р.В. Горбунов - } \\
\text { Врио директора ФГБУН «КНС ПЗ РАН» с } \\
01.12 .2015 \text { г. по настоящее время. } \\
\text { Издано: Писанець Є., Кукушкін О. Земноводні } \\
\text { Криму / НАН Украини; Національний науково- } \\
\text { природничий музей. - Київ, 2016. - } 320 \text { с.; } \\
\text { Амолин А. В., Фатерыга А. В. Семейство Vеspidae } \\
\text { - складчатокрылые осы // Определитель } \\
\text { насекомых юга России / Ред. К.С. Артохин, } \\
\text { Ю.Г. Арзанов, О.П. Негробов, А.Н. Полтавский. - } \\
\text { Ростов-на-Дону: Fоundation, 2016. - С. 875-887. }\end{array}$ \\
\hline
\end{tabular}

\section{Заключение}

Карадагская научная станция им. Т.И. Вяземского за прошедшие 100 лет сыграла большую роль в развитии различных областей наук - от геологии до морской гидробиологии. За годы ее существования здесь проводились многие интересные научные исследования, получены новые для науки данные. Благодаря станции здесь, на Карадаге, осуществилось становление многих выдающихся ученых в разных областях науки. Пророческими были слова А.Ф. Слудского (2004), высказанные им в опубликованных рукописных материалах «Мой разговор с моим отдаленным преемником на Карадаге», «Мои впечатления от Карадага через №-е число лет», где на вопрос: «В чьем ведении, или точнее ведомстве находится сейчас Карадагская станция?» находим ответ: «Она принадлежит всему Русскому государству». Хочется надеяться, что второе рождение станции, осуществленное в 2015 г. в связи с постановлением Правительства Российской Федерации под названием ФГБУН «Карадагская научная станция им.Т.И. Вяземского - природный заповедник РАН» будет способствовать активизации научной деятельности коллектива и дальнейшему росту авторитета станции как научного учреждения в системе Российской академии наук.

\section{Список литературы}

1. Виноградов К.А. Карадагская биологическая станция Академии наук Украинской ССР // Природа. - 1947 а. - № 10. - С. 81-83.

2. Виноградов К.О. Карадагська біологічна станція в системі Академії наук УРСР (1937-1947) // Вісник Академії наук УРСР. - 1947 б. - № 5. - С. 57-61.

3. Виноградов К.А. Карадагская биологическая станция им. Т.И. Вяземского Академии наук Украинской ССР // Очерки по истории отечественных гидробиологических исследований на Черном море. - Киев: Изд-во АН УССР. - 1958. - С. 61-72.

4. Виноградов К.А. Карадагская биологическая станция в системе Академии наук УССР (19371947) // Карадаг-2009: Сборник научных трудов, посвященный 95-летию Карадагской научной станции и 30-летию Карадагского природного заповедника Национальной академии наук Украины. - Севастополь: ЭКОСИ-Гидрофизика, 2009. - С. 20-24.

5. Владимирова Ж.К., Владимиров Е.И. Неизвестные страницы из истории Карадагской научной станции. От 90-летнего юбилея к 100-летию // Культура народов Причерноморья. - 2008. - № 147. - T. 2. - C. 45-80.

6. Клюкин А.А. Исследователь Карадага. К 120-летию А.Ф. Слудского // Карадаг. История, геология, ботаника, зоология / Сборник научных трудов, посвященный 90-летию Карадагской 
научной станции им. Т.И. Вяземского и 25-летию Карадагского природного заповедника. Книга 1-я. - Симферополь: СОНАТ, 2004. - С.28-37.

7. Колотилова Н.Н. Карадагская биостанция // Лекции по истории и экологии микроорганизмов: Летняя практика по экологии микроорганизмов: Учебно-методическое пособие / Отв. ред. А.Н. Петрусов. - М.: МАКС Пресс, 2013. - С. 3-14.

8. Липшиц С.Ю. Московское общество испытателей природы за 135 лет его существования (1805-1940) (исторический очерк). - М., 1940. - 136 с.

9. Михаленок Д.К. К 80-летию создания Карадагской научной станции им. Т.И. Вяземского // Труды Карадагского филиала Института биологии южных морей им. А.О. Ковалевского НАН Украины. 1994. - Севастополь. 1997. - С.134-144.

10. Михаленок Д.К. Свет науки: 85 лет Карадагской научной станции имени Т.И. Вяземского // Карадагский калейдоскоп. Калейдоскоп литературы, науки, искусства. Версия 1. Симферополь: Таврия. - 1999. - С.19-42.

11. Морозова А.Л. Предисловие / Карадаг. История, биология, археология / Сборник научных трудов, посвященный 85-летию Карадагской биологической станции им. Т.И. Вяземского. Симферополь: СОНАТ, 2001. - С. 5-6.

12. Морозова А.Л. 90 лет Карадагской биологической станции и 25 лет Карадагскому природному заповеднику // Карадаг. 90 лет Карадагской научной станции имени Т.И. Вяземского и 25 лет Карадагскому природному заповеднику / Материалы юбилейной сессии научно-технического совета, 2004 год. - Симферополь: СОНАТ, 2004. - С. 11-27.

13. Морозова А.Л., Каменских Л.Н., Михаленок Д.К. История изучения Карадага и создания Карадагского государственного заповедника // Природа Карадага. - Киев: Наукова думка, 1989. C.17-24.

14. Мороховец М.А. Страницы биографии профессора Л.З. Мороховца (1848-1919) // История медицины. - 2015. - Т. 2. - № 4. - С. 573-585.

15. Понизовский А.М. У самого Черного моря. Карадагская биологическая станция // Природа. 1965. - № 5. - С. 76-78.

16. Пузанов И.И. К пятидесятилетию Карадагской биологической станции // Гидробиологический журнал. - 1965. - № 1. - С. 75-78.

17. Слудский А.Ф. Мой разговор с моим отдаленным преемником на Карадаге. Мои впечатления от Карадага через N-ое число лет // Карадаг. История, геология, ботаника, зоология / Сборник научных трудов, посвященный 90-летию Карадагской научной станции им. Т. И. Вяземского и 25-летию Карадагского природного заповедника. Книга 1-я. - Симферополь: СОНАТ, 2004 а. C. $15-20$.

18. Слудский А.Ф. Карадагская научная станция // Карадаг. История, геология, ботаника, зоология / Сборник научных трудов, посвященный 90-летию Карадагской научной станции им. Т.И. Вяземского и 25-летию Карадагского природного заповедника. Книга 1-я. - Симферополь: COHAT, 2004 б. - С. 22-27.

19. Слудский А.Ф. Карадагская биологическая станция (исторический очерк) // Карадаг-2009: Сборник научных трудов, посвященный 95-летию Карадагской научной станции и 30-летию Карадагского природного заповедника Национальной академии наук Украины. - Севастополь: ЭКОСИ-Гидрофизика, 2009. - С. 9-19.

20. Смирнов А.Н. Карадагская биологическая станция // Карадаг. Научно-популярные очерки / А.Н. Смирнов, М.И. Котов, И.И. Пузанов, А.М. Дьяконов, Д.Л. Грищенко. - Киев: Изд-во АН УССР, 1959. - C.94-104.

Поступила 3 августа 2016 г. В окончательном виде 1 сентября 2016 г.

\section{HYSTORICAL REVIEW OF THE T.I. VYAZEMSKY KARADAG SCIENTIFIC STATION. N.S. Kostenko}

T.I.Vyazemsky Karadag Scientific Station - Nature Reserve of the RAS, Feodosia, Russian Federation, e-mail: karadag1914@mail.ru

Article describes results of the one hundred years time (1914-2014) research activity of the Karadag Scientific Station and its re-establishing according to the decision of the Russian Government in 2015. Key words: T.I. Vyazemsky Karadag Scientific Station. 